\title{
Breakout Financial Protection Encirclement: International Development Road of SWFs in China
}

\author{
Xiang Jing \\ Shenzhen WTO Affairs Center \\ School of Law, Fudan University \\ Room.C3143, Civic Center, 3rd Fuzhong Rd., ShenZhen , China \\ Tel: +86-133-3283-2263Ｅ-mail: carol.hsiang@163.com
}

Received: March 17, 2011 Accepted: May 5, 2011 doi:10.5430/rwe.v2n2p36

\begin{abstract}
In recent years, the foreign exchange reserves of our country rose sharply. In order to diversify foreign exchange risk and maximize the revenue of foreign exchange reserves, our country set up the first sovereign wealth funds (SWFs) in 2007, namely China Investment Corporation (CIC). The main source of funds was 200 billion dollars in foreign exchange reserves bought by Ministry of Finance from issuing 1.55 trillion yuan special treasury bonds. As a new SWF, CIC lacked proper investment management mechanisms and also faced high domestic expected investment return and a variety of investment impediments on international financial markets. Therefore, this paper will interpret how to breakout the shackles and cope with the uncertainty of the development process, and analyze the development and expansion road of SWFs in China.
\end{abstract}

Keywords: Financial Protection, Sovereign Wealth Funds (SWFs), China Investment Corporation (CIC), Development

1. Coexistence of Pressure and Resistance and the Interpretation of the Difficulties Faced on the Road to Development

\subsection{Tremendous Pressure from Macro Environment in China}

The establishment of CIC was not only a reform of foreign investment patterns, but also it shouldered the important task of laying out plans of economic development strategies and national resource strategies and completing the objective of maintaining and increasing the value of growing foreign exchange reserves. All these gave CIC enormous pressure.

1.1.1 CIC Played a Dual Role of Domestic Policy Investment and Overseas Market Investment and Shouldered the Triple Task

First, it injected capital to the state-owned commercial banks, joint-equity banks and policy banks and helped to restructure and IPO; second, it dealt with its assignment of non-performing assets and problematic brokers; third, it invested in overseas financial portfolio products. This had gone far beyond the scope of diversification of foreign exchange. How to effectively balance the limited resource in the triple task was the first challenge that CIC faced and also a fundamental problem that CIC needed to solve.

\subsubsection{Enormous Public Pressure and Profit Forecast Pressure}

2008 was a year in which the world was mired in the pain of economic crisis, and sovereign wealth funds also could not stay aloof. The world's leading SWFs had experienced a drastic shrinkage. The value of equities, real estate and other assets that they held declined up to 25\% last year, resulting in the loss of about 500 to 700 billion dollars, which made the total value of SWFs fall to between 2.3 trillion and 2.5 trillion dollars. CIC, which had been established for more than one year, also could not escape. The previous overseas investment, such as Blackstone Group, Morgan Stanley, Reserve Primary Fund, JPMorgan Chase's main money market funds, Deutche Asset Management's DWS Money Market Trust and so on, was nearly loss. However, according to $7 \%$ to $10 \%$ depreciation of the dollar in recent years and a $5 \%$ bond interest rate, the dollar return that CIC requested should be at least about $12 \%$ to $15 \%$ without considering the administrative costs. The average return of the world's SWFs was only 6\%, and the investment return of the leading SWFs was also only $10 \%$. The profit forecast pressure that CIC bore was large. 
1.1.3 As an Investment Institution that Shouldered a Special Mission, the Investment Behavior of CIC Should be Consistent with National Foreign Investment Policies

The law related to foreign exchange management in our country was only the regulations of one aspect of foreign exchange operation. The limit of business scope for CIC foreign exchange investment still had no special legal document so far, which made it difficult to operate legally. The SWFs separated from the legal economy was likely to result in unpredictable threats to the healthy development of the national economy.

\subsection{Development Pressure Closely Related to its Own Micro-Conditions}

\subsubsection{CIC Had the Governance Structure Defects}

Although CIC had a board of management institutions, supervisors, Party committees and management committees, but the respective position functions and division roles were not clear. At the same time, senior managers were almost all officials of domestic financial sectors. Though they had extensive management experience and profound knowledge, most lacked experience in foreign financial derivatives investment and SWFs investment management. More seriously, members of CIC came from different ministries and there were five non-executive directors which were national in-service leaders of relevant ministries. Once they were in disagreement on key issues, it was likely to translate into a conflict of interest among ministries. In addition, the appointment of management and asset management was decided directly by government, which made CIC not have true independence.

\subsubsection{Large Difficulty to Choose Investment Instruments and Products}

Under the current international situation, alternative investment products and instruments of CIC were few. The investment risks were large and the demand of investment techniques for managers was high. Particularly, CIC had been newly established and still lacked investment experience, and needed to face enormous difficulties in the aspects of investment object selection and timing. If it tried to achieve a stable return and invested heavily in strategic areas, such as energy, raw materials and others, it would lead to suspicions from host parties and bring invisible resistance and even open hostility.

\subsubsection{Overseas Investment of CIC Faced Competition of Other Domestic Financial Institutions}

After the establishment of CIC, SAFE significantly accelerated the investment pace of high-income products. Similarly, banks and non-bank financial institutions also stepped out of the country at this time and accessed to international financial markets, which no doubt formed a competition relationship with CIC in a way. The overseas investment return of agencies might be an important reference of the future foreign exchange reserves allocation of Chinese government. At that time, if the overseas investment return of CIC whose mission was to improve the foreign exchange reserves return was lower than that of SAFE and even social insurance funds which took safety first, then the criticism and pressure that CIC faced could be imagined.

\subsubsection{CIC Needed to Address the Problem of the Balance between Information Transparency and Business Secrets}

Developed countries thought that the unclearly judgment for investment behavior of SWFs was likely to cause instability in international financial markets. Coupled with the suspicious attitude of developed countries to the Chinese market economic system, this would lead them to a higher transparency requirement of CIC. On the other hand, as an investor, if the Chinese government could not understand the company's operating performance, then they would not grasp the management of funds. At the same time, the size of SWFs was huge. Some information might have a significant impact on the market and also might involve state secrets, so to maintain the confidentiality of their business was also very necessary. Therefore, how to balance between business secrets and information transparency and design a reasonable information disclosure system was another challenge for CIC.

\subsection{Resistance of Investing Host Countries}

The emergence of SWFs was a necessity of existing international financial system, such as the enhancement of emerging countries' economic and financial strength, the rapid development of intra-regional trade, international trade and investment activities, the imbalance appeared in the world economy, especially the huge U.S. trade deficit and the dollar's long-term slump, and so on. Although not a SWF had any bad behavior in the market in the last fifty years, the SWFs still induced investing host countries' aversion, guard and even obstruction.

1.3.1 CIC was Difficult to Get the Recognition of Host Countries and the Monitoring for CIC Became Increasingly Strict

CIC implemented the mixed investment strategies of domestic strategic investment and overseas portfolio investment, which inevitably led to doubts and resistance from host countries. Moreover, the international community generally 
believed that SWFs was controlled by government and there was inevitably political purpose other than commercial return. Therefore, SWFs would necessarily encounter many political obstacles in the investing process, and the monitoring of host countries over their equity investment became increasingly strict.

\subsubsection{European and American Developed Countries Implemented High-Standards Investment Access Policies for SWFs}

European and American developed countries implemented high-standards investment access policies for SWFs, which was undoubtedly a huge blow for Chinese SWFs. Political "China threat theory" and the massive foreign exchange reserves were sufficient to cause concern in many countries and would inevitably make policy barriers to prevent the funds from coming into their domestic markets. Therefore, CIC would get more qualification and more strict constraints for investment amount, area, yield and so on, when invested in access to international financial markets.

\subsubsection{CIC did not Meet the Conditions of State Immunity}

Although CIC represented the state to exercise specific functions, it mainly exercised "management right" given by the state rather than "sovereignty", which belonged to a non-sovereign behavior and did not meet the immunity of the jurisdiction under the "Convention". In addition, the operating assets of CIC was invested by the way that Ministry of Finance bought from the central bank through issuing special treasury bonds and invested in the way of registered capital, and no doubt belonged to legal property of CIC. This also did not conform to the conditions of immunity of implementation measures under the "Convention".

$<$ Table 1 about here $>$

\section{Breakout the Encirclement and Look for the Development and Expansion Road of CIC}

\subsection{Priority is to Improve the Internal Management Structure}

The current senior managers of CIC were almost all officials of domestic financial sectors. But investment professionals were relatively lacking and consequently CIC lacked an independent and creative think space needed by a successful investment agency. In fact, an investment company whose executive directors were formed by officials of state finance and financial ministries was difficult to achieve professional investment. By comparison, only four executive directors were from the official in the Temasek's ten board directors, and the other six are external. In order to achieve success, the first task of CIC was to insulate with other government departments and take more viewing and discussion of its own responsibilities, rights and obligations in practice. CIC should improve the internal management structure from the following four aspects.

\subsubsection{Carry on Different Positioning and Division of Labor}

According to different liquidity demands and risk requirements, CIC should divide SWFs into several funds and define their own investment objectives. Now, it should at least be divided into two independent SWFs which each have their own investing focus. The best position of CIC is the financial investor on international financial markets, which is similar to GIC in Singapore, to help the central government manage foreign exchange reserve assets. While the best position of Central Huijin Investment should be a strategic investor on the domestic and international financial markets, which is similar to Temasek in Singapore, to provide strategic help for long-term development of Chinese economy. CIC needs to be distinguished as clearly divided from Central Huijin Investment and best does not have any sense of equity relationships and other material relationship. Only this division framework is more easily to let host countries to believe that the investment behavior of CIC is pure market behavior, which is benefit for reducing the resistance of overseas investment.

\subsubsection{Strive for Independent Dominant Position and Establish a Sound Government Structure}

On the one hand, it should establish an independent dominant position as soon as possible to ensure that its decision-making and operation are free from administrative interference, and reduce the public misunderstanding of political interference or political mission; on the other hand, it should gradually establish a sound internal organizational structure, and clear job functions, roles divisions, governance patterns, management team, incentive restrictions, performance evaluation mechanisms and so on. The management needs of CIC can be filled by recruiting outstanding senior managers, and the government shareholders should make decisions through the Board. In the internal organizational structure and governance patterns, it should highlight the core decision-making functions and autonomy of the Board and professional investment committee and clear the responsibilities and profits, and make effective staffing allocation according to the requirements of simple and efficient organizational structure. Executive directors should establish investment guidelines and set clear boundaries for various departments in the system level, and the interior of the Board should also form the mutual balance of structure.

2.1.3 Vigorously Introduce Professionals, Optimize Staffing Allocation and Actively Communicate with International 
Top-Tier Investment Institutions

In the initial operation stage of foreign exchange investment company, it is necessary to establish an attractive salary system and attract experienced high-end international investment professionals to join in on a global scale, and accelerate training of the high level operational managers who expertly grasp international financial market investment skills. It can be detailed by the following four aspects: first, reduce the proportion of civil servants and government officials, especially in the setting of decision-making departments and board members, and introduce professionals with extensive experience in investment management; second, give fund managers full authority based on improving internal risk control system, and strengthen the restraint of fund senior managers, especially professional ethics; third, set standards for external fund managers on the aspects of management, research and development, team building and implementation of investment decisions, and strictly supervise; fourth, the salary should be set with reference to international practices, and the gains and losses should be linked with salaries.

\subsubsection{Improve Relevant Laws and Regulations}

In the process of multi-level management of foreign exchange assets, there needs to be established a complete decision-making and risk control mechanism and transparency in the form of laws and regulations. The state should establish laws to identify the subject nature of CIC, regulate its behavior, define its duties, enhance the asset management qualities and investment returns, strengthen supervision and risk control, promote it to operate healthily, and ensure the value of foreign exchange assets to maintain and increase. At the same time, it should seriously study the investment agreements between the home country and the investing host country of SWFs and the trade dispute settlement mechanism induced by SWFs to achieve win-win situations.

\subsection{Strengthen the Investment Management and Obtain Maximum Investment Return}

In order to achieve its Chinese economic development strategy, national resource strategic layout plan and the mission of maintaining and increasing the value of growing foreign exchange reserves, CIC must strengthen the investment management, strive to study and draw the right way of other SWFs and large pension funds, and develop a suite of prudent and strict investment decision-making mechanisms, internal control mechanisms and risk supervisory mechanisms according to complexity and changing characteristics of the world's financial markets, thereby obtaining maximum investment return.

\subsubsection{The Objective of Investment Return in the Initial Operation Stage should not be Set Too High}

Whether from the external international environment or the own situation of CIC, the investment return at this stage should not be set too high. $6 \%$ to $7 \%$ is more reasonable. It should be timely adjusted according to the actual situation after three years. Studying the investment return of SWFs needs a longer time period and there should not be a judgment of success or failure in a moment of gains and losses. Long-term investment is the core competence of SWFs, and must have the ability and desire of moving trends and also have the institutional arrangements to take short-term losses. It needs to balance the pressure of current earnings and long-term earnings, carefully weighing the risks and benefits of various products, resist the temptation of high-risk high-return products, and insist on value investment and not to be disturbed by short-term fluctuations.

\subsubsection{Establish Investment Strategy and Investment Directory}

According to national development strategies, CIC should choose the global investment projects associated with it, and develop a reasonable and coherent investment strategy. First, CIC should provide an investment objective, investment scope, asset portfolio and so on at the beginning of establishment. It should pursue the principles of diversification based on industry investment aspects and maintain a wide range of investment products, but the investment of the key industry and sensitive areas of recipient countries must be considered carefully. Second, CIC should actively explore and expand the investment channels of reserve assets, and the regional selection should not only be limited to Western countries, and should also focus on developing countries, especially the Asia-Pacific region and African countries. Third, CIC should appropriately develop foreign direct investment, such as the establishment of overseas developing investment funds, which leads the foreign exchange reserve assets to go out of the country orderly. In addition, on the aspect of constraining investment behavior, it should establish investment behavior guidelines based on the type, size and scope of investment behavior of investment institutions, and clear the adjustment principles of investment scale and speed, prohibited investment behavior and the consultation mechanism with investing host countries.

2.2.3 Improve and Regulate the Investment Process and Establish Effective Investment Management Decision-Making Mechanisms

The long-term capital allocation, the borne risk level, and the expected investment return are decided by Board of the 
company, and the management decides how to implement the decision of Board and then decides the development of the asset portfolios. On the aspect of the investment management decision-making mechanisms, first, it should enhance the vertical decision-making and the administrative officials should be involved in the decision-making more deeply on a strategic level, and at the same time it should refine the vertical management layers. Second, it should strengthen the subdivision of the horizontal dimension and make decisions according to different functions of foreign exchange reserves. Additionally, it should also consider the state's supervision, management and necessary investment decisions for this part of the funds. We should emphasize a "risk veto" principle when making investment decisions, which means that the risk regulators have the power of risk veto and supervise and guide the overseas investment activities of investment companies.

\subsubsection{Establish Sound Risk Control Mechanisms}

Measurement and prevention of risks are a prerequisite and key to scientific investment. CIC needs to establish a rigorous risk management system to avoid business failure caused by the accumulation of systemic risk. It should also analyze the investment environment of interested investing countries and rate these countries according to different investment sectors. Moreover, CIC needs to set a specialized risk control department to supervise the internal and external risks, clear boundaries among the various departments, and ensure the specialized supervision department to strictly supervise the audit of each funds department and guard against risks. Investment guidelines are required to clearly define the basic rules of risk control, and risk control can be executed by department managers in accordance with the basic rules. It should emphasize a "risk veto" principle and carry on pre-investment risk evaluation, in-investment risk management, and post-investment risk supervision.

\subsubsection{Building Performance Evaluation Systems}

In the long run, CIC needs to achieve the actual investment return that is higher than inflation rate of the G3 (dollar, Euro and yen). First, it should take independent accounting of domestic and overseas investments and establish different targeted performance evaluation mechanisms. Second, for the foreign portfolio investment business, the dollar or Euro-denominated return benchmark is difficult to measure the performance of SWFs because of the diversification of the investment. So we suggest that it should rebuild weighted index benchmarks according to different asset allocations and various international general asset indexes, or separately set evaluation criteria for assets from different areas. In addition, it should consider the factor of large interest repayment when evaluating performance.

\subsubsection{Strengthen the Multi-Form Cooperation with the Exterior, and Prepare and Plan the Overseas Investment of SWFs}

During initial operations, CIC does not have enough international market investment experience and still does not have a mature investment team, so it should strengthen the multi-form cooperation with the exterior, such as to adopt the strategy of cooperating with international institutional investors and the way of commission investment, establish the cooperating mechanism operated by SWFs of emerging countries in Asia, and so on, and learn to prevent risks and accumulate experience in this process. The Chinese government should take a comprehensive consideration and prepare and plan the overseas investment of SWFs, and establish capital output mode serving for national strategy. To make excellent and interactive competition and cooperation relationships in the course of overseas investment, and build up overseas investment teams with distinct arrangement and unique styles, which can not only improve the overseas investment efficiency of national institutions but also can avoid the unnecessary competition and conflict in the process of overseas investment to finally obtain a win-win situation.

\subsubsection{Establish a Sound Information Disclosure System}

CIC should balance between increasing transparency and maintaining business secrets and implement the information disclosure mechanism of "one company and two systems", which means that the core investment strategy and portfolios should be secret for the exterior and increase transparency for the interior. CIC should have specialized agencies to communicate with Ministry of Finance, the People's Bank and the State Department and report the operational information and the portfolio situation. The information disclosure should adopt the principle of limited disclosure and the more desirable way is post-transparency. If CIC develops to a reasonable stage, then it can publish regularly the investment portfolio reports audited by an international audit agency, so that the governments and the public sectors of other countries can understand investment ideas of CIC and eliminate political concerns. At the same time, the Chinese government needs to strengthen the access review and operating monitor of foreign SWFs. We must adhere to the principle of reciprocity when reviewing the market access safety of foreign SWFs, strengthen the tracking and monitoring of their investment behavior, enhance operational review and always put the objective of maintaining competitive advantage and safeguarding national security and national interests as a first priority.

\subsection{Make Efforts to Circumvent the Resistance of Host Countries and Successfully Enter the International Market}


At the same time of improving internal governance structure and strengthening investment management as soon as possible, CIC needs to break through the barriers of financial protectionism and make efforts to circumvent the resistance of the host countries and successfully enter the international market.

\subsubsection{Recognize the Political Nature of "Financial Protectionism” and Ease the Resistance Emotion}

CIC should consider the possibility of upgrading "financial protectionism” induced by the Western political change. It can use the differences of system to breakout the shackles when the countries have not gotten exactly the same position. The international investment banks are also the possible helpers. CIC can use their abilities of lobbying government and controlling to contain "financial protectionism". Even more importantly, it should establish a management system of SWFs that accords with the international trend, and take the methods accepted internationally to build SWFs. Moreover, CIC should also make a good communication with international organizations, such as the International Monetary Fund and the G7, enhance interpretation, emphasize the commercial purpose and release its good faith to ease the resistance emotion of "financial protectionism".

2.3.2 Temporarily Avoid Obtaining the Control Rights of Western Large Listed Companies and Appropriately Open Market Access Policies

In order to avoid political sensitivity, CIC should more explicitly announce its non-strategic investors and adopt a passive investment strategy which means that it takes the financial investment as the main objective, not to seek the company's control right, not to be involved in company management, also not to take any form of cooperation with the investment companies, and only pursue financial return, especially when accessing strategic industries of developed countries to seek equity investment. In certain circumstances, CIC should design reasonable or expedient flexible acquisition structures and explore the principles of reference type and incremental type. In addition, opening up the domestic market is a prerequisite to enter each other's markets, so CIC needs to enhance the negotiation with non-reciprocal open-market countries and regions and strive for more overseas investment space, especially the United States whose market opening degree is significantly lower than ours.

\subsubsection{Pay Close Attention to Situation and Actively Participate in the Formulation of SWF Management Rules}

CIC must take a systematic analysis approach of the legal environments in host countries before investing and avoid legal risks, and also pay close attention to their political changes, especially the economic policy changes related to investment. Regional or international organizations, such as the European Commission, the International Monetary Fund, the World Bank and so on, have already developed bilateral guidelines to standardize the behavior of SWFs and the host countries. In order to safeguard national interests, CIC should follow international practice and national laws to operate and also actively participate in the international discussions of developing SWF management rules to strive towards favorable results. The basic attitude that CIC should adhere to is that such legislation should be placed under the multilateral framework to ensure the broad participation of key stakeholders. We are opposed to a few countries to dominate related international legislation location, and insist to maintain the principle and flexibility of the code of conduct when participating. CIC needs to actively associate with the global SWFs to negotiate with resisting countries and establish a trade dispute settlement mechanism similar to WTO to resolve disputes appropriately.

\section{References}

A Closer Look at Sovereign Wealth Funds: Secretive, Powerful, Unregulated and Huge, December 12, 2007, ttp://knowledge.wharton.upenn.edu/article.cfm?articleid=1868).

Jeffrey Garten, We Need Rules for Sovereign Funds [J], The Financial Times, August, 2007.

Owen F·Humpage, Michael Shenk. Sovereign Wealth Funds [J], Economic Trends, July 2, 2007.

Richard Portes, Sovereign Wealth Funds: A Threat to Financial Stability? [J], Real IR, 18th September, 2007.

Sebastian Mallaby, “The Next Globalization Backlash”, Washington Post, June 25, 2007.

Stetten Kem, “Sovereign Wealth Funds-State Investments on the Rise”, Deutsche Bank Research, September 10, 2007.

U.S. Treasury Department. “Appendix 3” in Semiannual Report on International Economic and Exchange Rate Policies, June 2007.

US General Accounting Office, OECD, DB Research. 
Table 1. Formal control mechanisms for foreign investments in developed countries

\begin{tabular}{|c|c|c|c|c|c|}
\hline & US & JP & FR & $\mathrm{DE}$ & UK \\
\hline $\begin{array}{c}\text { Legal } \\
\text { framework }\end{array}$ & $\begin{array}{l}\text {-Exon-Florio } \\
\text { legislation, } \\
\text { International } \\
\text { Emergency } \\
\text { Economic } \\
\text { Powers Act }\end{array}$ & $\begin{array}{c}\text {-Foreign } \\
\text { Exchange and } \\
\text { Foreign Trade } \\
\text { Control Law } \\
\text { (FECL) }\end{array}$ & $\begin{array}{l}\text {-1996 Foreign } \\
\text { Investment Law }\end{array}$ & $\begin{array}{l}\text {-1961 Foreign } \\
\text { Trade and } \\
\text { Payments Act }\end{array}$ & $\begin{array}{c}\text {-Industry Act of } \\
1975 \\
\text { - Foreign Trade } \\
\text { Act of } 1973\end{array}$ \\
\hline $\begin{array}{c}\text { Reasons } \\
\text { for review }\end{array}$ & $\begin{array}{c}\text { - National } \\
\text { security }\end{array}$ & $\begin{array}{l}\text { - National } \\
\text { security }\end{array}$ & $\begin{array}{c}\text { - National } \\
\text { security }\end{array}$ & $\begin{array}{l}\text { - National } \\
\text { security }\end{array}$ & - national interest \\
\hline $\begin{array}{l}\text { Review } \\
\text { body }\end{array}$ & $\begin{array}{l}\text {-Committee on } \\
\text { Foreign } \\
\text { Investments in } \\
\text { the United } \\
\text { States (CFIUS) }\end{array}$ & $\begin{array}{l}\text {-Ministry of } \\
\text { Finance } \\
\text { - Ministry in } \\
\text { charge of the } \\
\text { industry }\end{array}$ & $\begin{array}{c}\text {-Ministry of } \\
\text { Economics and } \\
\text { Finance, } \\
\text { consulting with } \\
\text { Ministries of } \\
\text { Industry and } \\
\text { Defence }\end{array}$ & -Not applicable & - Not applicable \\
\hline $\begin{array}{l}\text { Review } \\
\text { process }\end{array}$ & $\begin{array}{c}\text { - 30D review } \\
\text { - } 45 \mathrm{D} \\
\text { investigation } \\
\text { - } 15 \mathrm{D} \\
\text { Presidential } \\
\text { review }\end{array}$ & $\begin{array}{c}\text {-30D review } \\
\text { - Max. extension } \\
\text { up to 5M }\end{array}$ & $\begin{array}{l}-1 \mathrm{M} \text { plus } \\
\text { postponement } \\
\text { rights }\end{array}$ & - Not applicable & - Not applicable \\
\hline Evidence & - 1 case blocked & $\begin{array}{c}\text { - None since } 1992 \\
\text { law revisions }\end{array}$ & $\begin{array}{l}\text { - } 9 \text { rejected in } \\
\text { 1992, 1993, } \\
1994 \text { for public } \\
\text { order reasons }\end{array}$ & $\begin{array}{c}\text { - Powers under } \\
\text { Foreign Trade } \\
\text { Law never } \\
\text { invoked }\end{array}$ & $\begin{array}{l}\text { - Powers under } \\
1975 \text { Industry Act } \\
\text { never invoked }\end{array}$ \\
\hline
\end{tabular}

Stetten Kem, “Sovereign Wealth Funds-State Investments on the Rise”, Deutsche Bank Research, September $10,2007$. US General Accounting Office, OECD, DB Research. 